\title{
Capital for an embattled industry: How hotel investors can tap into the debt market
}

Received (in revised form): 27 August 2003

\section{Henrik Bartl}

is Head of the International Hotel Financing Team of Aareal Bank AG, a specialised financial institution focusing on senior debt real estate lending in Europe and North America. He joined the bank in 1998 and established the specialised Hotel Lending Team. The Team handles both hotel mortgage and corporate financing transactions across major cities of the USA, Canada and Europe. Mr Bartl is responsible for the structuring, origination and execution of various forms of financing to the hospitality industry.

\section{Regina DiBenedetto}

is an Associate with Aareal Bank's International Hotel Advisory Group. Aareal Bank's International Hotel Advisory team provides financial and strategic investors with personal and competent advice on hotel transactions in Europe and elsewhere. The group also actively assists hotel owners in the management of their assets to maximise value. Prior to joining Aareal Bank, Ms. DiBenedetto was a consultant with an international firm in the USA. Past projects include market and competitive analyses, facilities programme recommendations, repositioning analyses and highest and best-use analyses, as well as financial and investment return analyses.

\section{Abstract}

To lay the framework as to why the time is right for investors to look into the hotel market and why lenders may be receptive to such projects, this paper commences with a discussion of real estate cycles. By taking a closer look at where the hotel real estate cycle stands, the investment and lending community may gain a perspective on the near to mid-term return potential of the industry.

The discussion will then turn to project-specific factors that shape up a potential investment to be perceived as a convincing deal by lenders, thereby opening the door to debt financing. This section will then be followed by an overview of current lending term trends.

As a result of the global recession, September 11th, and

Henrik Bartl

Aareal Bank AG

Paulinenstrasse 15

65189 Wiesbaden, Germany

Tel: +49611348 2930

Fax: +49611348 2246

E-mail: henrik.bart!@aareal-bank.com

Regina DiBenedetto

Aareal Bank AG

Paulinenstrasse 15

65189 Wiesbaden, Germany

Tel: +49611 3483104

Fax: +49611 3482246

E-mail:

regina.dibenedetto@aareal-bank.com ongoing declines in business travel, the industry has seen a rise in loan delinquencies, particularly for small properties in certain overbuilt markets. As such, the latter part of this paper will briefly review how lenders work with struggling borrowers to avoid foreclosure on quality properties which have recovery potential. Lastly, the paper will close with a discussion regarding key trends in hotel investment and financing.

\section{Keywords:}

hotel lenders, hotel investors, hotel loans, lending terms, real estate cycles, hotel investment outlook 


\section{INTRODUCTION}

Following a period of robust performance in 1999 and 2000, the hotel industry began to face copious uphill battles. From dealing with the gradual onset of a recession, experiencing a plummet in performance following the World Trade Center attacks and coping with the fallout of corporate scandals to surviving a bout with SARS, hoteliers continue to brace themselves, hoping no additional adverse events make their way on to this all-too-familiar list.

Despite the more certain post-war environment, fickle economies and geopolitical tensions are still causing fluctuations in the hotel industry's trajectory to stabilisation. Interestingly, from a contrarian point of view, it is precisely because the industry's course to recovery has not yet normalised that it is time for investors to take a closer look. Select global markets are beginning to display improving demand-side fundamentals and, within these markets, it is possible to find compelling hotel projects and financing despite generally conservative lending standards.

In the USA alone, as of March 2003, approximately $\$ 50-75 \mathrm{bn}$ is estimated to be on the sidelines looking for uniquely positioned real estate opportunities on which to lend or contribute equity. ${ }^{1}$ These figures must be tempered with a bit of caution, however, particularly if commercial real estate loan delinquencies increase further. While a further value dip could result in the availability of more 'bargain deals', it is also important to note that conservative lenders may flee the market, possibly causing the amount of available capital to diminish significantly. Furthermore, it is yet to be seen just how much of this available debt capital will be allocated to hotel financing.

\section{HOTEL REAL ESTATE CYCLE}

An essential prerequisite to hotel investments is a sound understanding of the industry's position on the real estate cycle both on a regional and a local market basis. With this knowledge, investors and lenders may gain a sense of return potential and risk exposure, thereby yielding smarter investment and financing decisions.

Recent real estate cycles have become less pronounced than those of the late 1980s and early 1990s. Since then, cycles have moderated, due primarily to more disciplined lending standards that have restrained chronic overbuilding and overleveraging. Furthermore, a greater degree of transparency has resulted from public real estate markets, including real estate investment trusts (REITs) and commercial mortgage-backed securities (CMBS). These factors have prevented the current hotel sector down cycle from having an even greater negative effect on the industry as it deals with the fallout of highly atypical events such as September 11 th, the war in Iraq and SARS.

Currently, one of the primary restraints on the hotel industry's recovery is mediocre corporate investment levels, which have caused 


\section{A new - but lasting - issue for the hotel real estate cycle}

a decline in employment, a continued stranglehold on business travel budgets and a decline in consumer confidence. To a lesser extent, ongoing concerns regarding air travel in terms of convenience, safety and availability of flights on major air carriers continue to impact on the industry. Mitigating this factor, however, is the proliferation of budget airlines in the USA and Europe, such as New York-based JetBlue, Ireland's Ryanair, Italy's Volare and the UK's Easyjet. These discount airlines have made air travel more accessible to a broader market, driving demand in various locations across the USA, continental Europe and the UK.

Another issue unique to the current hotel sector cycle is the introduction of the third-party online discount distributor. In response to the challenges faced during the past two years, hoteliers began to utilise online discount distribution channels to move their inventory, albeit while relinquishing rate integrity. The rate of internet reservations is anticipated to grow from 13-14 per cent of all bookings in 2003 to over 20 per cent by $2005 .^{2}$ In order to mitigate the trend of commoditising hotel rooms due to brand erosion, which could lead to chronic price erosion, hoteliers must regain control over their online marketing with direct-to-consumer online distribution strategies via proprietary sites.

It is interesting to note that, in light of these extraordinary events in the current hotel real estate cycle, bargain property sales did not pervade the market, for several reasons.

- Owners held on to quality properties, as offering prices did not reflect the future return potential of their hotels but instead focused on exceptionally poor performance during recent months.

- Owners with floating-rate loans have benefited from low interest rates, allowing them to hold on to their properties for a longer period of time.

- Otherwise willing sellers have simply refinanced their properties, taking advantage of low interest rates.

- Lenders have cooperated with owners of quality properties to avoid foreclosure by offering various concessions.

Yet the industry has seen a continuous flow in transactions in the USA and Europe involving quality properties, not only as a result of owners not being able to hang on to their hotels any longer due to cash shortages, but also due to the narrowing of the bid-ask spread. Investors who understand that key hotel assets do, in fact, hold attractive return potential have begun to cast more realistic offers.

Although moderate increases in average hotel room value may occur in 2003, overall hotel values are still depressed compared to 2000 levels as the poor performance of recent months has been factored into sales prices. In fact, according to HVS International, overall US hotel property prices declined approximately 23 per cent 


\section{Historical trends in supply versus hotel values}

and 5 per cent in 2001 and 2002, respectively, from prior year levels. ${ }^{3}$ Values for non-distressed hotel properties, however, are beginning to see an upswing. The question is what exactly these moderate increases are based upon. Two possibilities include:

- more realistic, forward-looking analyses of the industry's demand-side fundamentals that should deliver healthier levels of cash flow going into 2004 if economies in the USA and Europe continue to recover in order to boost consumer confidence and business travel;

- a decline in capitalisation and discount rates, both due to a more optimistic outlook for the industry and the lower cost of capital for the debt component.

Given these factors, carefully selected hotel markets may be entering the recovery and growth point of the sector's real estate cycle, placing segments of the hotel industry in a unique position to deliver significant returns over the mid-term.

Taking a look at historical supply and value trends provides additional insight regarding forthcoming return potential in the hotel industry. Historically, property prices have tended to rise even when the hospitality investment community began to raise red flags about overbuilding. For example, in the USA, prices continued to rise and reached record levels in the late 1980s despite overbuilding that had been evident since the mid-1980s. As such, when the 'bubble' burst with the onset of the 1991 recession, hotel values experienced sharp declines.

Since then, the hotel real estate cycle has followed a similar course, albeit in a more disciplined financing environment. Hotel values continued to rise through 2000 and 2001, despite indications of overbuilding in certain markets since the mid to late 1990s. Again, the industry was seeing hotel values rise in concert with significant increases in supply, leading towards a period of possible value declines to correct the market. The events of September 11th, however, accelerated the industry's cycle and the natural trend towards dips in property values. Furthermore, immediate reductions in new supply occurred, resulting in a 15.1 per cent decline in the hotel development pipeline during 2002 compared to the previous year. ${ }^{4}$ With new builds anticipated to grow only 1.8 per cent and 1.7 per cent during 2003 and 2004, respectively, the hotel construction pipeline clearly remains restrained as a large contingency of both investors and lenders remain wary of the industry. ${ }^{5}$

Thus, the industry appears to be in a trough of supply, set to grow gradually if economies continue to normalise. If historical trends associated with supply-side fundamentals are repeated, this points to another period in the near to mid-term during which hotel values are set to rise significantly. As such, investors seeking notable returns may find that further investigating the still- 
struggling hotel sector is worthwhile to find a strong project at a reasonable price before the industry begins to show clear signs of recovery and renewed optimism is priced into hotel sales. To illustrate, luxury properties are currently priced only marginally above replacement cost and are set to increase substantially at least through 2005 until an increase in supply once again causes a downward pressure on luxury hotel values. In contrast, the more heavily populated mid-scale property market is anticipated to trade well below replacement cost through 2004, not exceeding replacement cost until $2005 .^{6}$

\section{CHARACTERISTICS OF A COMPELLING DEAL}

Although average hotel values are down but poised to rise in the short to mid-term, supply and demand-side fundamentals bode well for a near-term improvement in operating profits, and lenders are paying renewed attention to the industry, while underwriting standards are still conservative. Lenders are looking only at very sound deals - projects that make sense in terms of location, concept and sustainable cash flow.

To determine whether a hotel project shapes up to be a 'good' deal, lenders will focus on four main issues - the asset, the market, the operator and the investor. Before extending a loan, lenders want to ensure operating conditions are optimal for the hotel to generate adequate cash flows to support the real estate investment, specifically to meet debt service obligations. Thus, the seasoned hotel investor will address the primary lending concerns summarised in Table 1 to optimise the probability of obtaining financing.

In addition to addressing these primary issues relating to the market, asset and borrower, the hotel investor should also consider the following points to increase the probability of obtaining hotel financing.

Hotels are a unique form of real estate investment, as the asset produces a variable cash flow. As such, a key element in the planning process is the creation of a business plan. The plan sets forth critical information that indicates the hotel's viability as an operating business and ability to deliver desired returns on equity as well as to meet debt service obligations. A series of important questions are answered in the business plan, a few of which are outlined here. What is the hotel's strategic positioning? Why is this the best location? What are the target market segments? How do the facilities and amenities meet the needs of these segments? How does this property fit into the selected brand's domestic and global portfolio? What will the sales and distribution strategies be - both via traditional mediums and online?

The business plan will be reviewed in conjunction with market studies and appraisals conducted by third parties, and the lender will assess if the 'pieces fit'. That is, are the contents of the business plan clear and action-oriented, and is it realistic given the market 
Table I: Primary lending concerns

Primary issues - Market and asset
Macro and micro location and corresponding market
performance
Recent and anticipated visitation levels and demand
generators
Existing, under construction, planned and rumoured
competitive properties

Physical description of property

Prospective five- to ten-year operating results and historical performance data for existing properties

Estimated open market value and corresponding discount and capitalisation rates

Selected brand affiliation and hotel management company

\section{Primary concerns}

Profile of the selected country, city and neighbourhood character and economic indicators

Hotel performance trends in these markets

Trends in visitation to the area

Visitor market origin and market segmentation - lenders prefer market diversity

Current and anticipated demand drivers for defined market segments

Degree of existing and anticipated competition and proximity to subject hotel

Ability of subject hotel to penetrate market share

Assessment of barriers to entry

Physical placement - accessibility and visibility

External and internal architecture and design

Appropriateness of positioning in market

Physical programme to determine whether blend of

rooms with facilities and amenities is in accordance with

planned positioning and market

Ability to drive top line and manage expenses

Effect of future market conditions on performance

Stability of cash flows

Interest and debt coverage ratios

Potential appreciation in asset value

Determine the appropriate loan to value ratio and corresponding loan amount

Assess appropriateness of discount and capitalisation rates utilised to obtain value in relation to market and projectspecific information

Appropriateness of brand for hotel's positioning

Brand recognition - domestic and international

Access to global distribution channels

Historical performance of management company

Key management contract terms, such as termination

rights and management fees

Potential for value appreciation

Ability to offer guarantees

Lease contracts

Where the operator leases the hotel, the lender will be interested in the lessee's ability to pay the rent and the underlying performance of the asset

\section{Primary concerns}

\section{Primary issues - Borrower}

Other assets the borrower owns and corresponding levels of debt service

Borrower's commitment to project

Borrower's track record in meeting debt service obligations

Experience in hotel investment (ie knowledge of the operating business)
Determine whether borrower is overleveraged Gain insight on which lenders the borrower has previously worked with as an indication of the borrower's perceived reliability

For recourse loans, obtain value of other assets Reach a comfort level with borrower's dedication to project by considering both the borrower's equity participation and the knowledge base Assess likelihood that borrower will meet debt service payments in a timely fashion and adhere to loan agreement covenants

Determine whether the borrower understands the hotel business - if so, the borrower is better equipped to deal effectively with the management company and operating issues

and quality of the existing or proposed asset? If the property in question is an existing property, the lender would be interested in whether the business plan has been adhered to and whether it has been continually updated to reflect true market conditions. A 


\section{Select the right hotel operator and brand}

\section{Share business risks with hotel operator}

strong, relevant business plan will give the lender a comfort level with the overall concept and planned execution of the project.

Selecting the right hotel operator and brand is highly important to the lender. The appropriateness of the brand and the effectiveness of the operator will play a large role in determining whether the property is positioned and managed correctly to attract the intended customer segments and deliver planned performance targets. Brand association is very important for most hotels to benefit from brand recognition, reputation, marketing power and distribution channels. The importance of branding has been exemplified during the past two years, since most hotel sales that have occurred as a result of default have involved older independent hotels that could not compete with branded properties. Lenders will be particularly interested in whether the operator's management capabilities are strong enough to deliver desired financial results.

Hotel operators are now sharing the business risk of running a hotel with the implementation of different fee structures and guarantees for both leases and management contracts. Doing so adds another level of comfort for both the owner and lender as the operator now holds a stake in the hotel, giving an added incentive to manage the property efficiently. Yet, in some cases, giving the operator a stake in the hotel may require the property owner to relinquish some control.

Turnover-based leases have become quite common. This lease structure allows the investor to limit downside potential by receiving a minimum amount of rent, regardless of hotel performance. When gross operating profit exceeds a predetermined level, however, rent levels increase, allowing the owner to share in the hotel's upside potential. Similarly, contracts that are based upon management fees typically include a base fee plus a performance-based incentive fee.

Management contracts are also increasingly including performance guarantees, particularly in Europe where almost half of all agreements include operator guarantees. ${ }^{7}$ That is, during the guarantee period, which is typically during the first few years of the hotel's operation, the operator guarantees a specified minimum net operating income (NOI). If the hotel falls short of this guarantee level, the operator must pay out the difference between the actual NOI and the guarantee level. Although the owner may have to pay back this guarantee payment over time when hotel performance exceeds the hurdle rate in future years, the guarantee agreement provides the owner with liquidity and downside yield protection.

Additionally, the hotel operator may be a source of equity or debt capital (mezzanine financing), giving them a larger stake in the performance of the hotel and, therefore, forging a more integrated relationship between owner and manager. But there are trade-offs, as in the case of equity contributions, where the operator becomes a partial owner and therefore gains even greater control over the asset. In addition, debt financing provided by an operator may 


\section{Develop a stabilised underwriting NOI}

\section{Consider mixed-use developments}

cause the owner to be subject to restrictive covenants in accordance with the loan agreement.

Recent financial statements clearly do not do the potential of quality hotels justice, which is why hotel lenders typically focus on both historical and prospective financials. As such, when approaching lenders for hotel financing, borrowers should be prepared with both recent financial information as well as explanations as to why significant performance variations took place and why these do not realistically reflect the hotel's performance potential. This information will assist lenders in developing stabilised NOI projections that truly reflect the property's ability to deliver strong financial results in the absence of the highly atypical events the industry has experienced during the recent years. The process of developing stabilised NOI projections will allow the lender to focus on the property's true potential rather than on a narrow snapshot in time where unprecedented events and geopolitical uncertainties severely depressed hotel performance.

Mixed-use developments provide diversified cash flow streams from various property types, plus they often attain synergies among the distinct real estate components. In addition, proceeds from residential sales provide an up-front cash injection, defraying construction costs. When financed as a complete development, these aspects may be viewed as attractive risk mitigants for hotel lenders. In practice, however, it is more common for lenders to evaluate each component separately while also considering the benefits of mixed-use development synergies and subsequent value creation. In both cases, the combination of a hotel asset with other appropriately positioned property types may bode well for the hotel's future performance expectations, thus potentially making the asset more attractive to lenders.

\section{TRENDS IN LENDING AND CONTRACT TERMS}

Borrowers with a competitive project and a receptive lender will proceed to negotiate lending terms. Lenders clearly continue to be disciplined in light of the industry's challenges not only in recent years but also due to lessons learned in the early 1990s.

Furthermore, the level of cautiousness varies significantly with the type of loan sought, whether it is for construction, a new build, an acquisition or a refinancing project. According to the 2003 US Federal Reserve Board Senior Loan Officer Opinion Survey ${ }^{8}$ of foreign banks located in the USA, credit standards for approving applications for commercial real estate loans have eased during the past two years. Underlying loan terms such as loan to value (LTV) ratios have remained largely unchanged, though there has been a continued moderate lessening of debt coverage ratio (DCR) requirements in comparison with the January 2001 and 2002 survey results.

Borrowers with qualified projects may stand to benefit from increased competition among lenders seeking compelling hotel 


\section{Various types of hotel loans, various levels of difficulty}

\section{Current trends in hotel lending terms}

projects. Already, during 2003 in the USA, spreads have narrowed by as much as 50 basis points for commercial real estate as a whole. ${ }^{9}$ This competition has increased in recent months due to weakened demand for loans on a global basis, as many potential borrowers err on the side of caution and remain 'on hold', waiting for a clear economic turnaround and more certainty before pushing new projects forward. If hotel performance continues to improve, however, and lenders become more optimistic about the industry's future prospects, margins could begin to widen in the near term.

Borrowers will find that obtaining financing for new builds, particularly construction financing, is far more challenging than sourcing debt for acquisitions of existing hotel properties or refinancing. New construction financing continues to run dry as cautious lenders prefer to see a history of performance to gain a better understanding as to how the asset is performing within the marketplace. As a result, the US hotel industry is still seeing restrained levels of new supply, and refinancing of existing properties constitutes a large proportion of loans originated in recent months. During 2004, refinancing in the USA is anticipated to accelerate as a significant amount of existing loans will become due. Meanwhile, in London, where cash flows have been quite volatile in recent months, many of the aggressively financed hotels in 1999 and 2000 may require refinancing, particularly when they become due in 2005 through to 2007. The same trend is not anticipated for Europe as a whole since hotels outside of London were, in general, more conservatively financed. The Asia Pacific region experienced a similar spike in refinancing during 2002 due to non-performing or underperforming loans, which were pooled by public asset management companies and sold to the private sector at significant discounts.

To date, the senior lending environment remains disciplined, as the following highlights regarding loan terms describe.

\section{Term}

Hotel loan terms have shortened, particularly in Europe, where terms are now typically five to ten years as compared with seven to 15 or even 20 years in the past.

\section{Loan to value}

LTV ratios have increased, based upon transaction values, albeit slightly. In the USA, for example, LTV ratios moved from 62 per cent in 2002 to 65 per cent in 2003, ${ }^{10}$ while in Europe LTV ratios remain slightly higher at $65-70$ per cent.

\section{Debt coverage ratio}

DCR requirements vary widely and are determined on a deal-bydeal basis. Furthermore, the DCR may be calculated using a variety of variables. For example, the lender may utilise trailing 12 month (TTM) or stabilised cash flows and actual, swap or 
Lenders may offer various concessions prior to foreclosure hypothetical interest rates in deriving the DCR. As such, although more lenders are focusing less on TTM and more on stabilised cash flow, given the abnormal circumstances of the past two years, overall DCR trends are not possible to pinpoint.

\section{Amortisation levels}

In recent months, some hotel loan amortisation levels have increased in order for the lender to recover a greater amount of the principal, thus minimising their risk exposure. Overall, however, the estimated average amortisation period during 2002 and 2003 has remained relatively stable at 22 years. ${ }^{11}$

\section{Prepayment penalties}

Prepayment penalties are now active over a longer period of time to protect the lender against the risk of early repayment. This is a particular concern if the property's cash flow is stronger than anticipated, as the borrower may attempt to refinance at a lower interest rate once the hotel's performance has been proven.

\section{DEALING WITH A STRUGGLING BORROWER}

During the first quarter of 2003, according to Fitch Ratings, CMBS loan delinquencies increased by 14 per cent to $\$ 2.8 \mathrm{bn}$, with hotel and office properties making the greatest impact on this increase. Specifically, hotel loans accounted for 35 per cent of the $\$ 2.8 \mathrm{bn}$ in delinquent CMBS loans. ${ }^{12}$ Clearly this means that hotel lenders will continue to rely on conservative lending standards for some time to come. Fortunately, due to disciplined lending standards thus far, only a few borrowers with quality, well-located projects have become delinquent on their loans during the past couple of years. Instead, several have gone into technical default rather than monetary default, meaning that certain loan covenants cannot be met, such as DCR requirements, but the borrower is still able to make payments.

When borrowers are in technical default and may be in danger of monetary default due to prolonged periods of strained cash flow, lenders may offer preventive concessions to avoid delinquencies and foreclosures for those assets with strong future earning potential. Such concessions may include the following.

- Extend the loan term.

- Conduct cash sweeps to apply all excess NOI directly to the outstanding principal of the loan, accelerating amortisation and decreasing the debt burden on the borrower.

- Adjust or waive selected loan covenants so that the borrower is no longer in technical default.

- Lower monthly debt service payments by offering a temporary forbearance period or extending the amortisation period.

The last concession listed above is rarely enacted, as it does not 
serve to ease the overall debt burden on the borrower since amortisation is not accelerated. As such, this option is only utilised when the property is no longer producing cash flows to do otherwise but holds the potential to meet debt service obligations in the future.

\section{OUTLOOK}

Clearly, the hospitality industry has several factors working in its favour - low interest rates, a low inflationary environment, reduced supply, normalising economies, anticipated increases in cash flow in the short to mid-term, upward value potential and available debt capital. Recognising these unique conditions, private equity hotel funds have been formed and are actively looking to take advantage of well-poised hotel projects throughout the globe to capture the anticipated upside potential. These funds are anticipated to continue to play an active role in hotel investments in the near to mid-term.

Other sources of private equity include high-net-worth individuals and pension funds which, in the USA, were estimated to allocate approximately 3.4 per cent of their investments to the hotel sector in 2003, according to the National Council of Real Estate Investment Fiduciaries (NCREIF). ${ }^{13}$ The greater amount of equity chasing quality hotel projects has placed an upward pressure on prices for such projects, preventing price levels from falling or mitigating the extent to which they have decreased due to the industry's recent challenges. Both private equity hotel funds and pension funds are more likely to have greater access to debt at favourable lending terms as compared with independent hotel investors, due to their size, expertise and track record. As a result of these factors, the remainder of 2003 and 2004 should continue to see a boost in the number of hotel transactions.

\section{Oversupply for some European markets}

\section{City-centre properties remain favoured by lenders}

Investors may be wary, however, of several European markets that may soon face significant levels of oversupply. According to a recent estimation by Jones Lang LaSalle Hotels, the total amount being invested in new hotel developments throughout Europe from 2003 to 2005 is a staggering $\$ 5.3$ bn. ${ }^{14}$ While some locations clearly require additional quality room inventories and have the potential to absorb high levels of new supply, investors entering the European hotel market are advised to gather all available information about new supply, whether it is under construction, planned or rumoured. Table 2 may serve as an initial guide for investors seeking opportunities in the European hotel market.

In terms of hotel sectors, quality four- to five-star city centre properties will continue to be favoured by hotel lenders. These areas typically present higher barriers to entry, not only due to construction and land costs, but also due to zoning and development regulations that impose special, and often costly, requirements - particularly for historical sites. City centre locations are also favoured because they frequently receive a diverse 
Refinancing to grow, mezzanine debt to play larger role

\section{Fewer hotel lenders possible}

Table 2: European hotel markets - Potential winners and losers

\begin{tabular}{lll}
\hline $\begin{array}{l}\text { Weakening market demand }- \\
\text { Significant supply increase }\end{array}$ & $\begin{array}{l}\text { Weaker market demand }- \\
\text { Less onerous supply increase }\end{array}$ & $\begin{array}{l}\text { Healthy supply and demand } \\
\text { balance }\end{array}$ \\
\hline Madrid & Berlin & London \\
Barcelona & Manchester & Amsterdam \\
Brussels & Munich & Paris \\
Dusseldorf & Stockholm & Milan \\
Frankfurt & Vienna & Rome \\
Budapest & & Birmingham \\
Cologne & & Cardiff \\
Warsaw & Edinburgh \\
& & Hamburg \\
& & Prague \\
\hline
\end{tabular}

Source: Jones Lang LaSalle Hotels’ European Digest (2003)

market segmentation between corporate, leisure and group travellers. As such, these factors contribute to the increased liquidity of the asset since they become attractive to a larger pool of potential future investors.

In the USA, refinancing volumes for hotel loans in CMBS pools will fluctuate through 2006 with $\$ 0.75 \mathrm{bn}, \$ 1.05 \mathrm{bn}, \$ 0.59 \mathrm{bn}$ and $\$ 0.40$ bn maturing during the years 2003 to 2006, respectively. In 2007 and 2008, maturing CMBS hotel loans are anticipated to swell to $\$ 2.29 \mathrm{bn}$ and $\$ 4.40 \mathrm{bn}$, respectively. ${ }^{15}$ Thus the sheer volumes of refinancing anticipated, coupled with deteriorations in the fundamentals for most sectors of commercial real estate since 2001, are anticipated to result in a greater opportunity for mezzanine lenders to play a larger role in hotel lending. Due to the strains imposed on commercial real estate during the past two years particularly on office and hotel properties — underwriters have been decreasing both anticipated revenues as well as occupancy rates to lower the lending value upon which LTV ratios are computed. As such, both mezzanine lending and additional equity injections will be required to close the gap - but clearly at a higher cost to the borrower - with the mezzanine interest rate typically ranging from 14 to 16 per cent.

Lastly, another ongoing trend that the hotel industry may continue to see during the remainder of 2003 through to 2004 is a decline in the number of available hotel lenders. In light of past real estate down cycles, several banks in the USA and Europe have already downsized or eliminated their overall commercial real estate lending divisions. Furthermore, bank consolidation, particularly in Europe, continues to reduce the number of available hotel lenders. For example, in August 2002 in Germany, Eurohypo was formed by consolidating Deutsche Hyp, the old Eurohypo and Rheinhyp. The extent of the industry's anticipated recovery in forthcoming months will play a role in whether current hotel lenders will close up shop. If this occurs, the playing field of hotel lenders will shrink, potentially diminishing the upside for borrowers of increased competition among lenders. 
In short, although the recent landscape of the hotel investment market has been riddled with setbacks and continues to deal with several uncertainties, especially pertaining to the economy and business travel, it still presents strong investment opportunities. The long-term dynamics of the hotel sector's supply and demand-side fundamentals will assist in driving performance in the near to midterm, particularly for branded properties in prime locations.

Because the current downturn is more heavily weighted on demandside factors rather than supply-side issues, as experienced in the early 1990s, it is anticipated that improved performance could occur within a shorter timeframe once demand improves further, as the market will not be absorbing a large overhang of supply at the same time. As such, forward-looking hotel investors can use the current window of opportunity to harness the upside potential of strong hotel projects by tapping into the hotel debt market and making deals happen within an otherwise rugged terrain.

\section{References}

1. Buss, N. (2003) '2003 real estate market outlook', PNC Real Estate Finance, March.

2. Starkov, M. (2003) 'Brand erosion, or how not to market your hotel on the web Revisited - Critical online distribution issues revisited a year later', Hotel News Resource, June, www.hotelnewsresource.com.

3. Rushmore, S. (2003) 'Recent economic and value trends for the US lodging industry', Hotel News Resource, July, www.hotelnewsresource.com.

4. Gluckler, P. (2003) 'At 1Q, migration of projects up the development pipeline nearing a trickle', Lodging Econometrics, April.

5. Gluckler, P. (2003) 'Developers reacting to the slower than hoped for recovery', Lodging Econometrics, July.

6. Rushmore, ref. 3 above.

7. Jones Lang LaSalle Hotels (2001) 'Management agreement trends worldwide', Hotel Topics, June.

8. US Federal Reserve Board (2003) Senior Loan Officer Opinion Survey on Bank Lending Practices, April.

9. Fickes, M. (2003) 'No slowdown for CMBS lenders', National Real Estate Investor, July.

10. 2003 Hospitality Investment Survey, PKF Consulting, www.pkfonline.com.

11. Sangree, D. (2003) 'Hotel capitalization rates drop', US Realty Consultants, Inc., February. See www.ishc.com/library/2003/caprate.doc.

12. Chapman, P. and Valley, M. (2003) 'Have we hit bottom?', National Real Estate Investor, July.

13. Fickes, M. (2003) 'Pension funds plan to plow \$14B into real estate in 2003', National Real Estate Investor, February.

14. See www.hotelnewsresource.com/article6639.html.

15. Charter Research, CMBS database, www.cmbs.com. 